\title{
Agrobacterium-mediated transformation of rough lemon (Citrus jambhiri Lush) with yeast HAL2 gene
}

Shawkat Ali ${ }^{1,2,3^{*}}$, Abdul Mannan ${ }^{1,4}$, Mohamed El Oirdi ${ }^{2}$, Abdul Waheed ${ }^{5}$ and Bushra Mirza ${ }^{1}$

\begin{abstract}
Background: Rough lemon (Citrus jambhiri Lush.) is the most commonly used Citrus rootstock in south Asia. It is extremely sensitive to salt stress that decreases the growth and yield of Citrus crops in many areas worldwide. Over expression of the yeast halotolerant gene (HAL2) results in increasing the level of salt tolerance in transgenic plants.

Results: Transformation of rough lemon was carried out by using Agrobacterium tumefaciens strains LBA4404 harboring plasmid pJRM17. Transgenic shoots were selected on kanamycin $100 \mathrm{mg} \mathrm{L}^{-1}$ along with $250 \mathrm{mg} \mathrm{L}^{-1}$ each of cefotaxime and vancomycin for effective inhibition of Agrobacterium growth. The Murashige and Skoog (MS) medium containing $200 \mu \mathrm{M}$ acetoseryngone (AS) proved to be the best inoculation and co-cultivation medium for transformation. MS medium supplemented with $3 \mathrm{mg} \mathrm{L}^{-1}$ of 6-benzylaminopurine (BA) showed maximum regeneration efficiency of the transformed explants. The final selection of the transformed plants was made on the basis of PCR and Southern blot analysis.
\end{abstract}

Conclusion: Rough lemon has been successfully transformed via Agrobacterium tumefaciens with $\beta$-glucuronidase (GUS) and HAL2. Various factors affecting gene transformation and regeneration efficiency were also investigated.

Keywords: Genetic transformation, Yeast halotolerant gene (HAL2), Citrus jambhiri Lush and Agrobacterium tumefaciens

\section{Background}

Genetic transformation of Citrus is a valuable technique for Citrus improvement due to difficulties of conventional Citrus breeding. In Citrus, gene transformation is carried out by three different techniques i.e., particle bombardment [1] protoplast transformation [2] and Agrobacterium [3-7]. Agrobacterium mediated transformation is the most commonly used method for gene transfer to Citrus as it does not need embryogenic calli and is protoplast independent [2]. Agrobacterium mediated gene transformation have been reported for a number of Citrus species by different groups [8-10]. However the transformation efficiency is still relatively low for some Citrus species and is cultivar dependent [11-13]. Rough lemon (C. jambhiri Lush.) originated from Himalayan foothills in India and Pakistan, is the commonly used Citrus rootstock in riverland of South Australia, lemon growing area of Arizona [14], south Asia, and in Pakistan it is used as rootstock for

\footnotetext{
*Correspondence: shawkatali77@hotmail.com

'Department of Biochemistry, Quaid-i-Azam University, Islamabad, Pakistan

${ }^{2}$ Département de Biologie, Université de Sherbrooke, Québec, Canada

Full list of author information is available at the end of the article
}

more than $90 \%$ of citrus fruit plants. Rough lemon is very vigorous rootstock and produce high yield performance in early years [14]. Besides this it propagate quickly, produces well developed root system and result in producing large tree [14]. Its resistance to Tristeza virus and drought tolerance together with other quality mentioned make it rootstock of choice in citrus growing areas of Pakistan. On the other hand rough lemon is extremely sensitive to salt stress which is the inherited problem in irrigated soil. Besides this it is also susceptible to blight, alternaria leaf spot (Alternaria citri) and to foot rot (Phytopthora parasitica). To overcome these problems genetic transformation of rough lemon is very important for future of Citrus production. We have previously reported micropropagation of rough lemon [15] which is a prerequisite for Agrobacterium mediated transformation. The objective of this study was to evaluate the effect of different factors on gene transformation of rough lemon (C. jambhiri Lush.) in order to optimize the protocol that could be used routinely for genetic improvement, and also to transfer yeast HAL2 gene to produce salt tolerant transgenic plants.

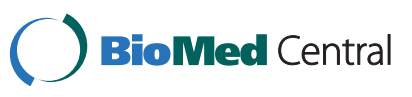

(c) 2012 Ali et al.:licensee BioMed Central Ltd. This is an Open Access article distributed under the terms of the Creative Commons Attribution License (http://creativecommons.org/licenses/by/2.0), which permits unrestricted use, distribution, and reproduction in any medium, provided the original work is properly cited. 


\section{Results and discussion}

\section{Optimization of selection condition}

For efficient and reliable production of transgenic $C$. jambhiri plants, optimization of the most suitable selection conditions is essential. The addition of a selective agent like kanamycin in the cultured medium is beneficial for competition of transformed cells with nontransformed ones and to decrease the number of escapes. The explants (stem and leaf) of untransformed plants were cultured on MS medium supplemented with $3.0 \mathrm{mg} \mathrm{L}^{-1}$ of BA containing various concentrations of kanamycin $\left(0,25,50,100,200 \mathrm{mg} \mathrm{L}^{-1}\right)$. Shoot regeneration was inhibited at the concentration of $50 \mathrm{mg} \mathrm{L}^{-1}$ of kanamycin in stem as well as in leaf segments as shown in Table 1. Concentrations of $100 \mathrm{mg} \mathrm{L}^{-1}$ and above resulted in complete bleaching and death of stem explants while in leaf explants $200 \mathrm{mg} \mathrm{L}^{-1}$ of kanamycin result in complete death (Figure 1, Table 1). Therefore, $100 \mathrm{mg} \mathrm{L}^{-1}$ kanamycin was used for selection of the explants throughout this work. It has been reported that $50 \mathrm{mg} \mathrm{L}^{-1}$ kanamycin completely inhibited shoot formation in non-transformed explants in trifoliate orange and hence $100 \mathrm{mg} \mathrm{L}^{-1}$ kanamycin was used for effective selection of transformed explants [16]. Pena and his group used $100 \mathrm{mg} \mathrm{L}^{-1}$ kanamycin for selection of transformed plants of different species of Citrus [9,17]. Different genotypes of Citrus may be resistant to slightly different concentration of selective agents like kanamycin in this study. Therefore it is important to investigate the sensitivity of untransformed explants before conducting any experiment of transgenic plant production.

\section{Effect of inoculation media on transient expression}

In order to select the best inoculation media three different types of media were tested in the transformation experiment in this study; LB medium, hormone free MS medium and MS medium supplemented with $200 \mu \mathrm{M}$ AS. None of the explants inoculated in LB or hormone free MS media produce kanamycin resistant shoots while $60 \%$ of the explants inoculated in MS medium with $200 \mu \mathrm{M}$ AS produced kanamycin resistant shoots.

Table 1 Influence of kanamycin dose on regeneration of the non-transformed explants

\begin{tabular}{lll}
\hline $\begin{array}{l}\text { Kanamycin } \mathrm{mg} \mathrm{L}^{-1} \text { in } \\
\text { regeneration } \\
\text { medium }\end{array}$ & $\begin{array}{l}\text { Average(Percentage } \pm \mathrm{SE}) \\
\text { of segments producing } \\
\text { shoots }\end{array}$ & $\begin{array}{l}\text { Standard } \\
\text { deviation }\end{array}$ \\
\hline 0 & $45(62.5 \pm 0.4282)$ & 1.0488 \\
\hline 25 & $36(50 \pm 0.2582)$ & 0.6325 \\
\hline 50 & $0.0(0 \pm 000)$ & 0.0000 \\
\hline 100 & $0.0(0 \pm 000)$ & 0.0000 \\
\hline 200 & $0.0(0 \pm 000)$ & 0.0000 \\
\hline
\end{tabular}

Note. Data represent the mean value of three independent experiments. 50-75 explants were used in each experiment.
Each experiment was repeated three times with a total number of 80 explants. In all following experiments MS medium supplemented with $200 \mu \mathrm{M}$ AS was used as inoculation medium for transformation. It has been shown that the addition of $20 \mu \mathrm{M}$ AS to the inoculation media increase the transformation efficiency of Citrus paradisi [10]. A similar increase in transformation efficiency has been reported for lentil (Lens culinaris M.) by addition of $200 \mu \mathrm{M}$ AS to inoculation medium [18].

\section{Effect of co-cultivation media on transient expression}

To select a suitable co-cultivation medium, four different types of media were used in the transformation experiments in this study, i.e. plain MS medium, MS medium supplemented with $100 \mu \mathrm{M}$ AS, MS medium supplemented with $200 \mu \mathrm{M}$ AS and MS medium supplemented with $200 \mu \mathrm{M}$ AS and $0.2 \mathrm{mg} \mathrm{L}^{-1}$ 2,4-Dichlorophenoxyacetic acid (2,4-D). Transient expression efficiency of explants on these media are shown in the Table 2. The MS medium supplemented with $200 \mu \mathrm{M}$ AS showed maximum transformation efficiency (44\%). The MS medium supplemented with $0.2 \mathrm{mg} \mathrm{L}^{-1}$ 2,4-D and $200 \mu \mathrm{M}$ AS and MS medium supplemented with $100 \mu \mathrm{M}$ AS showed transient expression efficiency of $26 \%$ and $25 \%$ respectively. The lowest transient expression efficiency was observed on plain MS medium. AS a plant phenolic compound produced in wound sites of plant, an inducer of the vir genes in A. tumefaciens [19]. The use of AS during co-cultivation has been shown to increase Agrobacterium-mediated transformation frequencies [20]. In carrizo citrange explants the addition of AS to co-cultivation medium increased the transformation frequency two fold [7]. Its beneficial role has also been demonstrated in transformation of some woody fruit, like apple [21] and kiwifruit [22]. Kaneyoshi et al. [16] reported the use of AS during co-cultivation of Poncirus trifoliate Rad. explants with Agrobacterium; however its role, as transformation enhancer was not investigated by them. The addition of certain auxins, especially 2,4-D, increase transformation frequencies in some Citrus species, $(9,17)$. We conduct an experiment to investigate the effect of 2,4-D in combination with the $200 \mu \mathrm{M}$ AS. Unexpectedly, the addition of this growth regulator in combination with AS decreased the transient expression efficiency. The possible explanation for this could, be that the addition of 2,4-D with AS decrease the transient expression but the efficiency of stable transformation will still be high. An alternative could be that as we transferred our explants after three days of co-cultivation into a medium that contains cytokinine instead of auxin as we want to get direct shoot regeneration without going to callusing and this could have an adverse effect. 


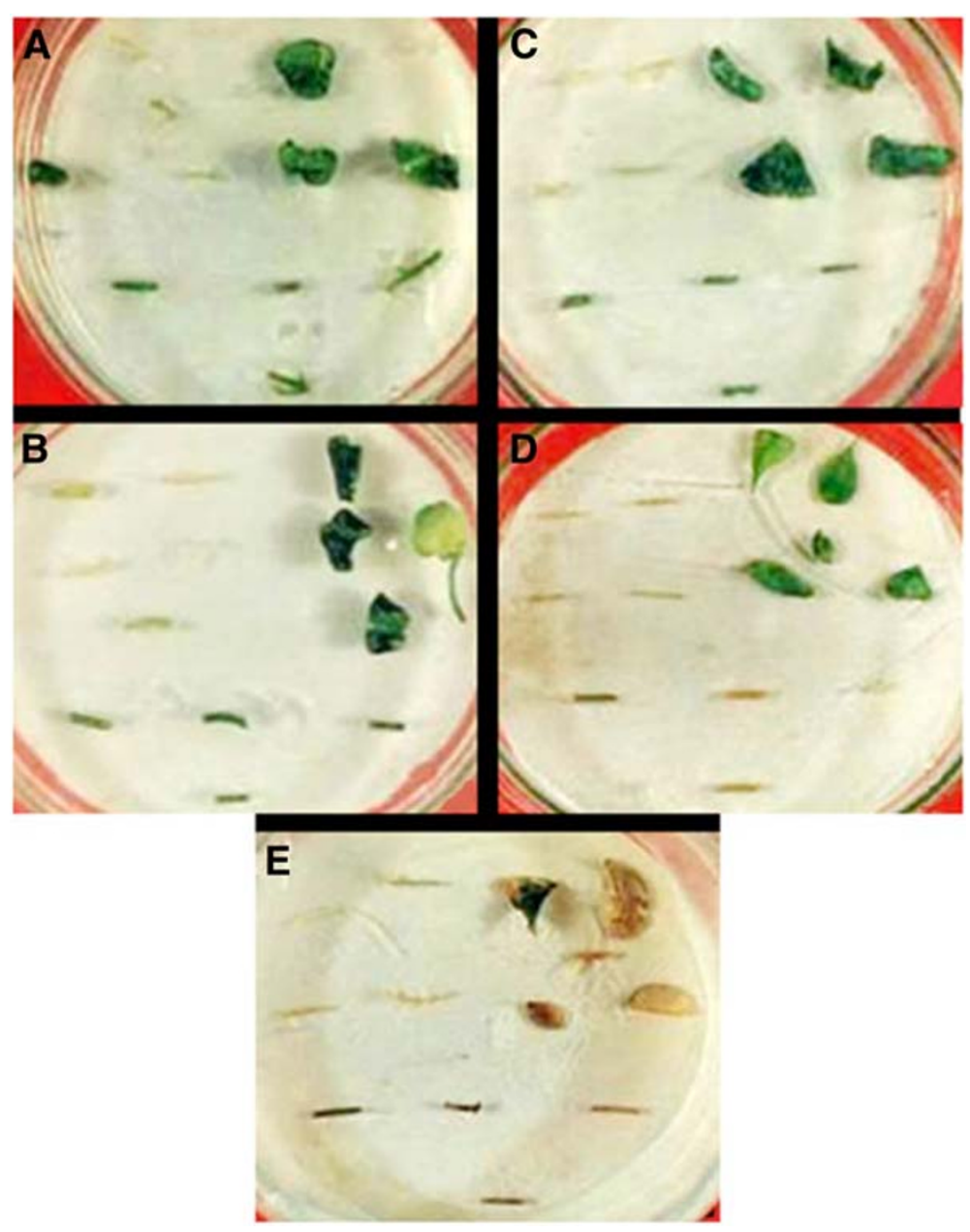

Figure 1 Sensitivity of the untransformed explants (0.5-1 cm pieces of leaves and stem segments) were tested by putting explants in Petriplates in MS medium supplemented with kanamycin at concentration of (A) $0 \mathrm{mg} \mathrm{L}^{-1}$, (B) $25 \mathrm{mg} \mathrm{L}^{-1}$, (C) $50 \mathrm{mg} \mathrm{L}^{-1}$, (D) $100 \mathrm{mg} \mathrm{L}^{-1}$, and (E) $200 \mathrm{mg} \mathrm{L}^{-1}$. The plates were incubated in growth chamber at $27^{\circ} \mathrm{C}, 16 \mathrm{~h}$ of photoperiod, illumination of $45 \mu \mathrm{HE} \mathrm{m} \mathrm{s}^{-2}$ and $60 \%$ relative humidity for 14 days. The pictures were taken 2 weeks post incubation in MS medium.

Table 2 Influence of the co-cultivation media on transient expression efficiency of the rough lemon plants

\begin{tabular}{lll}
\hline $\begin{array}{l}\text { Types co-cultivation } \\
\text { media }\end{array}$ & $\begin{array}{l}\text { Average (Percentage } \pm \text { SE) } \\
\text { of segments producing } \\
\text { shoots }\end{array}$ & $\begin{array}{l}\text { Standard } \\
\text { deviation }\end{array}$ \\
\hline Plain MS medium & $5(5.55 \pm 0.3333)$ & 0.5774 \\
\hline $\begin{array}{l}\text { MS medium }+100 \mu \mathrm{M} \\
\text { acetoseryngone }\end{array}$ & $23(25.55 \pm 0.6667)$ & 1.1574 \\
\hline $\begin{array}{l}\text { MS medium }+200 \mu \mathrm{M} \\
\text { acetoseryngone }\end{array}$ & $40(44.44 \pm 0.6667)$ & 1.1174 \\
\hline $\begin{array}{l}\text { MS medium }+200 \mu \mathrm{M} \\
\text { acetoseryngone+ } 0.2 \mathrm{mg} \mathrm{L}^{-1} \\
\text { 2,4-D }\end{array}$ & $24(26.66 \pm 0.5774)$ & 1.000 \\
\hline
\end{tabular}

Note. Data represent the mean value of three independent experiments. 75-100 explants were used in each experiment.

All media contains MS salts and vitamins.

\section{Effect of hormone concentration and combination on regeneration}

To select a suitable medium for regeneration of putative transformed (kanamycin resistant shoots), three different types of media were used. All media used for regeneration were supplemented with $100 \mathrm{mg} \mathrm{L}^{-1}$ kanamycin sulphate for selection and either $500 \mathrm{mg} \mathrm{L}^{-1}$ cefotaxime alone or $250 \mathrm{mg} \mathrm{L}^{-1}$ cefotaxime and $250 \mathrm{mg} \mathrm{L}^{-1}$ vancomycin in combination for control of bacterial growth. Regeneration efficiency of explants on MS medium supplemented with $3 \mathrm{mg} \mathrm{L}^{-1}$ of BA was $40 \%$ and on MS medium supplemented with $2 \mathrm{mg} \mathrm{L}^{-1} \mathrm{BA}$ and $0.1 \mathrm{mg} \mathrm{L}^{-1}$ of Naphthalene acetic acid (NAA), was 30\% while on hormone free MS medium it was only $1.6 \%$ as shown in the Table 3. MS medium supplemented with $3 \mathrm{mg} \mathrm{L}^{-1}$ of BA or with $5 \mathrm{mg} \mathrm{L}^{-1}$ of BA has been used for regeneration of different species of Citrus by several laboratories $[17,24]$. MS medium supplemented with $5 \mathrm{mg} \mathrm{L}^{-1} \mathrm{BA}$ 
Table 3 Influence of hormone concentration and combination on regeneration

\begin{tabular}{lllc}
\hline Medium & $\begin{array}{l}\text { No of } \\
\text { segments of segments producing } \\
\text { cultured }\end{array}$ & $\begin{array}{l}\text { Average (Peots } \\
\text { shoontage } \pm \text { SE) }\end{array}$ & $\begin{array}{l}\text { Standard } \\
\text { deviation }\end{array}$ \\
\hline $\begin{array}{l}\text { Hormone free MS } \\
\text { medium }\end{array}$ & 60 & $1(1.66 \pm 0.500)$ & 0.7071 \\
\hline $\begin{array}{l}\text { MS medium }+3 \mathrm{mg} \\
\mathrm{L}^{-1} \mathrm{BA}\end{array}$ & 90 & $36(40 \pm 1.00000)$ & 1.7321 \\
\hline $\begin{array}{l}\text { MS medium }+2 \mathrm{mg} \\
\mathrm{L}^{-1} \mathrm{BA}+1 \mathrm{mg} \mathrm{L^{-1 }} \mathrm{NAA}\end{array}$ & $27(30 \pm 0.5774)$ & 1.0000 \\
\hline $\begin{array}{l}\text { Note: All media contain MS salts and vitamins, Data represent the mean value } \\
\text { of three independent experiments. }\end{array}$
\end{tabular}

and $0.1 \mathrm{mg} \mathrm{L}^{-1}$ NAA was used for the regeneration of $P$. trifoliate [16], while Costa et al. [25] reported shoot regeneration on BA from $0.5-4 \mathrm{mg} \mathrm{L}^{-1}$ with the best at $2 \mathrm{mg} \mathrm{L}^{-1}$ for Citrus paradisi (Macf) epicotyl explants. For citrange the best regeneration was obtained at $5 \mathrm{mg} \mathrm{L} \mathrm{L}^{-1}$ of $\mathrm{BA}$ [7]. However the percentage regeneration response in all these reports is quite low. Based on our results we used MS medium supplemented with $3 \mathrm{mg} \mathrm{L}^{-1}$ for regeneration in further experiments. Again here the regeneration efficiency may be genotype or cultivar dependent and a careful investigation may be required before conducting transgenic plant production experiments.

\section{Effect of antibiotics on control of Agrobacterium during shoot regeneration}

To control Agrobacterium growth during shoot regeneration, $500 \mathrm{mg} \mathrm{L}^{-1}$ of cefotaxime alone or $250 \mathrm{mg} \mathrm{L}^{-1}$ cefotaxime and $250 \mathrm{mg} \mathrm{L}^{-1}$ vancomycin were used. Results showed that cefotaxime alone did not inhibit Agrobacterium growth. However cefotaxime in combination with the vancomycin effectively inhibited the Agrobacterium growth during shoot regeneration. In some experiments, Agrobacterium start its growth again when regenerated transformed shoots were transferred to fresh medium without vancomycin after 4 weeks and these regenerated shoots died due to Agrobacterium over growth. Therefore in further experiments, cefotaxime and vancomycin in combinations were used for two months during shoot growth. For effective control of Agrobacterium growth in regeneration medium, Kaneyoshi et al. [16] used cefotaxime $500 \mathrm{mg} \mathrm{L}^{-1}$, while other group used cefotaxime $250 \mathrm{mg} \mathrm{L}^{-1}$ and vancomycin $250 \mathrm{mg} \mathrm{L}^{-1}$ in combination [13]. However, after 4 week they did not use any antibiotic for Agrobacterium control while in our experiment Agrobacterium start its growth again when antibiotics were omitted. It seems that vancomycin and cefotaxime did not kill Agrobacterium at this concentration but restrict its growth, which grew again when there was no selection pressure. It may be the reason that in some other experiments, higher concentration of cefotaxime $500 \mathrm{mg} \mathrm{L}^{-1}$ and vancomycin $250 \mathrm{mg} \mathrm{L}^{-1}$ in combination has been used $[17,24]$.

\section{Rooting of transformed plants}

For rooting, the developed shoots cut off segments were cultured on MS medium supplemented with $0.5 \mathrm{mg} \mathrm{L}^{-1}$ NAA or $1 \mathrm{mg} \mathrm{L}^{-1}$ 2, 4-D. We obtained $70 \%$ and $50 \%$ rooting results in these two media respectively. Low rooting efficiency has been previously reported as major problem for in vitro production of Citrus plants [26]. Difficulties in inducing roots have been found in transformation procedures of tree species, like walnut [27], apple [28], plum [29] and carrizo citrange [30] and have resulted in low production of regenerated transgenic plants. Peña et al. [13] used MS medium supplemented with $3 \mathrm{mg} \mathrm{L}^{-1} \mathrm{NAA}$ for rooting of sweet orange and got only $3.2 \%$ rooting after 3 months of transferring shoots to rooting medium. However, similar to our results, $81.1 \%$ rooting on MS medium supplemented with $0.5 \mathrm{mg} \mathrm{L}^{-1} \mathrm{NAA}$ was reported for trifoliate orange [16].

\section{Histochemical Gus assay}

The leaves and stem segments cocultivated with Agrobacterium strain LBA4404 harboring plasmid pJRM17 for three days were stained with GUS substrate by incubating for several hours at $37^{\circ} \mathrm{C}$. Non-transformed explants showed no GUS activity when stained with (5bromo-4-chloro-3-indolyl glucuronide (X-Gluc), while explants which were transformed showed blue spots (Figure 2).

\section{Molecular analysis of transformed plants}

For molecular analysis of transformed plants, PCR and Southern blots were used to detect the transfer and integration of the Neomycin phosphotransferase (NPTII) and HAL2 gene. Fifty-five kanamycin resistant (putative transformed) plants were produced with HAL2 genes.

For PCR analysis DNA was extracted from healthy kanamycin resistant regenerated plants. A predicted

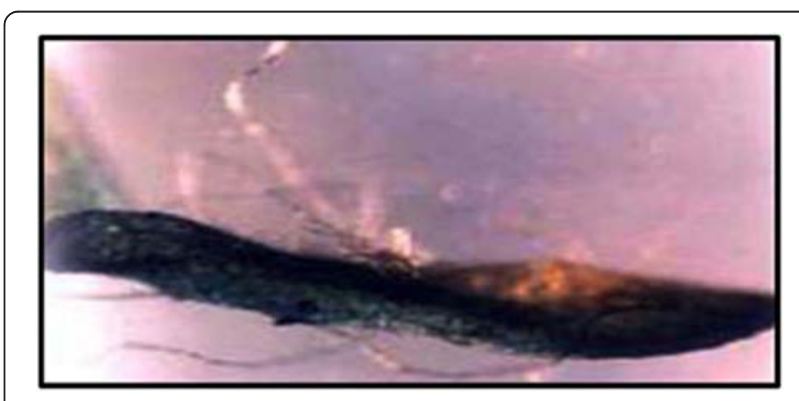

Figure 2 Transient GUS expression in explants. Transient GUS gene expression in stem segment explants was observed immediately after co-cultivation with A. tumefaciens strain LBA4404/ pJRM17. 
internal fragment of the NPTII gene of about 1021 nucleotides was amplified in three individual plants as shown in the Figure 3. No amplification was found in samples from non-transgenic control plants. The same size fragment was also amplified from plasmid pJRM17.

To determine the stability and randomness of $\mathrm{T}$ DNA integration DNA was isolated from PCR positive transformed plants, and one untransformed plant as a negative control for Southern analysis. A single fragment of $1.6 \mathrm{~kb}$, of expected size was observed for all six transgenic plants (Figure 4A) when an internal probe for the HAL2 gene was used. This analysis confirm that all the transgenic plants were stably transformed, however it did not verify a single or random integration of the T-DNA as this was an internal probe for the T-DNA (Figure 4A). To see the randomness of the T-DNA integration and to confirm that these were independent transgenic plants, we performed another blot in which we used the probe for the GUS gene close to RB of the T-DNA and DNA was digested by restriction enzyme KpnI. As shown in the (Figure 5) each band in this blot should represent a single T-DNA insertion. At least five of the transgenic plants analyzed gave a different size junction fragment (Figure 4B) indicating a random integration of T-DNA in different parts of the genome. We did not see a clear visible band for two PCR positive transformants, which could be the result of T-DNA truncation at the right border and no band was observed in untransformed control plant. T-DNA truncation is common during Agrobacterium mediated transformation of plants but it is more common at right boarder than left border [31-33].

\section{Conclusion}

The present research work results in successful transformation of HAL2 gene in rough lemon using Agrobacterium tumefaciens strains LBA4404.

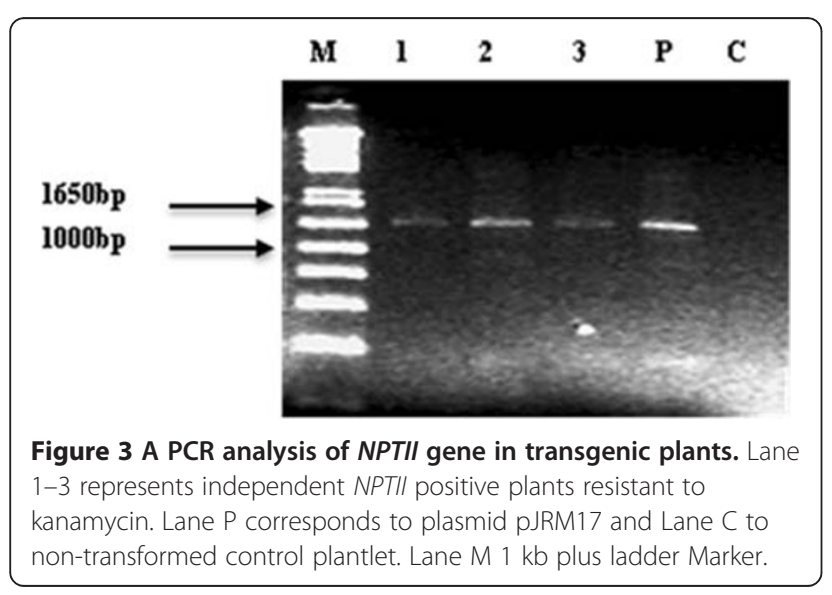

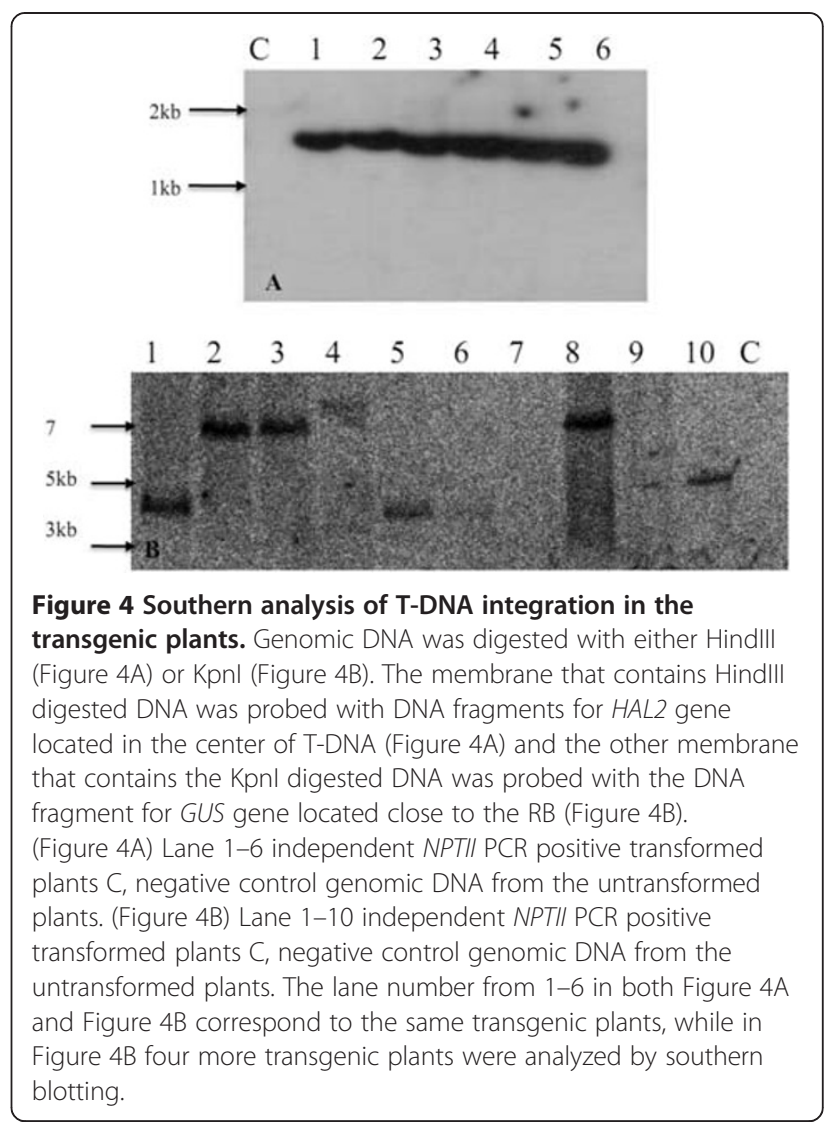

\section{Methods}

\section{Preparation of explants}

Seeds of C. jambhiri (Lush) were peeled removing both seed coats, disinfected in $0.1 \%(w / v)$ Mercuric Chloride for $5 \mathrm{~min}$ and rinsed thrice with autoclaved doubled distilled water. The seeds were then placed individually in culture tubes containing $25 \mathrm{ml}$ of MS medium [34], containing 5\% sucrose and solidified with $0.8 \%$ agar. The $\mathrm{pH}$ of all plant tissue culture media used in this study was adjusted to $\mathrm{pH} 5.75$, with $\mathrm{HCL}$ and $\mathrm{NaOH}$, while the $\mathrm{pH}$ of $\mathrm{LB}$ media was adjusted to 7.5. The media with the culture tubes was autoclaved before placing the seeds. For germination, the cultures tubes were incubated in darkness at $27^{\circ} \mathrm{C}$ for 2 weeks and then at $25^{\circ} \mathrm{C}$, in growth chamber with $16 \mathrm{~h}$ of $45 \mu \mathrm{E} \mathrm{m}^{-2} \mathrm{~s}^{-1}$ photoperiod and $60 \%$ relative humidity for 3 weeks. Leaves and stem segments were excised from 5-week-old in vitro grown seedlings and cut into $0.5-1 \mathrm{~cm}$ pieces, which were used as explants for further manipulation.

\section{Binary vector and bacterial strain used}

Agrobacterium tumefaciens strains LBA4404 [35] harbouring plasmid pJRM17 [36] was used for the transformation of rough lemon. The structure of the T-DNA region of 


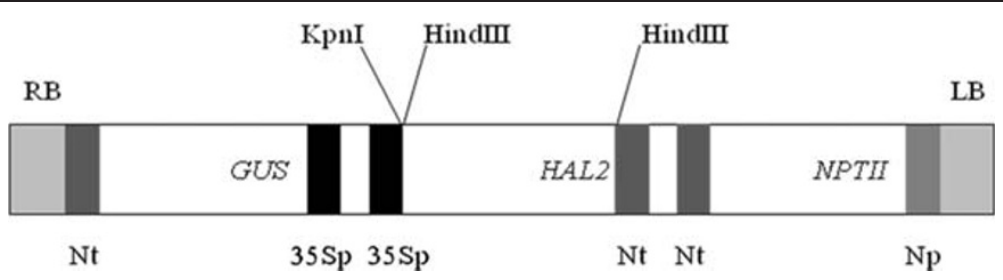

Figure 5 Structure of the T-DNA region of the plasmid pJRM17. The 7.4 kb DNA fragment between the right (RB) and left (LB) borders; Np: nopaline synthase gene promoter; Nt: nopaline synthase gene polyadenylation and transcription terminator site; 35 Sp: cauliflower mosaic virus 35 S promoter; GUS: $\beta$-glucoronidase coding region of the bacterial gus A gene; NPTII: neomycin phosphotransferase coding region of the bacterial NPTII gene; HAL2: fragment containing the coding region of the yeast HAL2 gene.

pJRM17 carrying three chimeric genes is shown in the (Figure 5). The full description of plasmid JRM17 is describe by Arrillaga et al. [36]

\section{Preparation of inoculum}

A. tumefaciens strain LBA4404 harboring plasmid pJRM17 was grown overnight in $50 \mathrm{ml}$ liquid LB medium pH 7.5 containing $50 \mathrm{mg} \mathrm{L}^{-1}$ kanamycin sulphate and $30 \mathrm{mg} \mathrm{L}^{-1}$ rifampicine at $28^{\circ} \mathrm{C}$ in shaking incubator at $200 \mathrm{rpm}$. Bacterial cells were collected by centrifugation at $4000 \mathrm{rpm}$ for $15 \mathrm{~min}$ and resuspended in inoculation medium. The density of bacteria was adjusted to approximately $5 \times 10^{8} \mathrm{CFU} \mathrm{ml}^{-1}$.

\section{Transformation procedure}

The stem and leaf explants were cut transversely from 5 -week-old in vitro grown seedlings and then immersed in the bacterial suspension for $20 \mathrm{~min}$ in three different media (LB, plain MS and MS medium containing $200 \mu \mathrm{M}$ AS). Thereafter the segments were blotted on sterilized filter paper and placed onto a co-cultivation medium in petri plates. Four different types of media were used for co-cultivation (plain MS medium, MS medium with $100 \mu \mathrm{M}$ AS, MS medium with $200 \mu \mathrm{M}$ AS and MS medium with $0.2 \mathrm{mg} \mathrm{L}^{-1} 2$, 4-D and $200 \mu \mathrm{M}$ AS). The co-culturing of explants was carried out in growth chamber at $27^{\circ} \mathrm{C}, 16 \mathrm{~h}$ of photoperiod, illumination of $45 \mu \mathrm{E} \mathrm{m} \mathrm{m}^{-2} \mathrm{~s}^{-1}$ and $60 \%$ relative humidity for 3 days.

After co-cultivation for three days, the explants were washed with sterilized MS medium containing either $500 \mathrm{mg} \mathrm{L}^{-1}$ cefotaxime alone or $250 \mathrm{mg} \mathrm{L}^{-1}$ cefotaxime and $250 \mathrm{mg} \mathrm{L}^{-1}$ vancomycin in combination, to control bacterial growth and blotted on sterilized filter paper. The segments were then transferred for shoot regeneration to the medium supplemented with $100 \mathrm{mg} \mathrm{L}^{-1}$ kanamycin sulphate for selection and either $500 \mathrm{mg} \mathrm{L}^{-1}$ cefotaxime alone or $250 \mathrm{mg} \mathrm{L}^{-1}$ cefotaxime and $250 \mathrm{mg} \mathrm{L}^{-1}$ vancomycin in combination for control of bacterial growth. Three different types of media were used for shoot regeneration (hormone free MS medium, MS medium supplemented with $3 \mathrm{mg} \mathrm{L}^{-1} \mathrm{BA}$, MS medium supplemented with $2 \mathrm{mg} \mathrm{L}^{-1} \mathrm{BA}$ and $\left.0.1 \mathrm{mg} \mathrm{L}^{-1} \mathrm{NAA}\right)$. The cultures were maintained at $27^{\circ} \mathrm{C}, 16 \mathrm{~h}$ of $45 \mu \mathrm{E} \mathrm{m} \mathrm{m}^{-2} \mathrm{~s}^{-1}$ photoperiod and $60 \%$ relative humidity. After 4 weeks, segments with adventitious shoot were transferred to MS medium supplemented with $0.5 \mathrm{mg} \mathrm{L}^{-1} \mathrm{BA}, 100 \mathrm{mg} \mathrm{L}^{-1}$ kanamycin sulphate, $250 \mathrm{mg} \mathrm{L}^{-1}$ cefotaxime and $250 \mathrm{mg} \mathrm{L}^{-1}$ vancomycin to allow further shoot development. For rooting, developed shoots segments were cultured on MS medium, supplemented with $0.5 \mathrm{mg} \mathrm{L}^{-1} \mathrm{NAA}$ or $1 \mathrm{mg} \mathrm{L}^{-1} 2$ - 4-D.

\section{Histochemical Gus assay}

$\beta$-glucuronidase (GUS) gene is the most commonly used reporter gene in plant transformation studies. Transient GUS expression was observed in leaf and stem segments after co-cultivation period of 3 days. The GUS assay was carried out according to the method of Jefferson et al. [37]. The leaf and stem segments were incubated in XGluc solution consisting of $1 \mathrm{mg} \mathrm{L}^{-1} \mathrm{X}$-Gluc, $0.5 \%$ triton $\mathrm{X}-100,20 \%$ methanol and $50 \mathrm{mM} \mathrm{NaH} \mathrm{PO}_{4}, \mathrm{pH}$ 7, for several hours at $37^{\circ} \mathrm{C}$. The chlorophyll was removed by several washes with $70 \%$ ethanol. Assayed tissues were observed under microscope.

\section{Molecular analysis}

For the confirmation of transformation and integration of the NPTII and HAL2 gene, molecular analysis was carried out through PCR and southern blotting.

For PCR analysis, genomic DNA was isolated from leaves of the transformed plants as well as untransformed plants by simplified CTAB method [38]. PCR was used to confirm the presence of NPTII gene (1021 bp) using the primers NPTIIF 5'AAGATGGATTGCACGCAGGTTC3 ' and NPTIIR 5'-GAAGAACTCGTCAAGAAGGCGA-3' following the standard protocol. The reaction conditions were as follows: $5 \mathrm{~min}$ of $95^{\circ} \mathrm{C}$ for template denaturation followed by 25 cycles of amplification of $30 \mathrm{~s}$ at $95^{\circ} \mathrm{C}$; one minute at $55^{\circ} \mathrm{C}$ and one minute at $70^{\circ} \mathrm{C}$ and final extension of $10 \mathrm{~min}$ at $70^{\circ} \mathrm{C}$. PCR was performed using Gene Amp PCR system 2400 thermocyclers (Perkin Elmer, USA).

For southern blotting, genomic DNA was extracted as described above. A $20 \mu \mathrm{g}$ of total DNA was digested with 
either HindIII, or KpnI, separated by gel electrophoresis in $0.8 \%(\mathrm{w} / \mathrm{v})$ agarose gel, in $1 \mathrm{X}$ Tris-borate-EDTA (TBE) buffer ( $89 \mathrm{mM}$ Tris base, $89 \mathrm{mM}$ boric acid, $2 \mathrm{mM}$ EDTA pH8.0). The DNA from gel was transferred overnight to a Hybond-N + membrane as recommended by the supplier (Amersham Biosciences/GE healthcare). To label the probe, P32-dCTP was used, using the Rediprime II Random Prime Labeling system (AmershamBiosciences/GE healthcare). The membrane was hybridized at $42^{\circ} \mathrm{C}$ in the ULTRA-hyb buffer (Ambion) according to the manufacturer's instructions. The blots were washed at $42^{\circ} \mathrm{C}$, three time, 5 min each with $2 \mathrm{X}$ SSC $(0.3 \mathrm{M}$ sodium chloride, $0.03 \mathrm{M}$ sodium citrate, $\mathrm{pH} 7.0)$ and $0.1 \%(\mathrm{w} / \mathrm{v})$ sodium dodecyl sulfate (SDS). Another two washes was carried out for 15 min each wash in $0.1 \mathrm{X}$ SSC and 0.1\% SDS. The blots were exposed to Kodak Biobax film (Kodak Canada, Toronto, ON, Canada).

\section{Abbreviations}

BA: 6-Benzylaminopurine; CFU: colony Forming Unit; NAA: naphthalene acetic acid; 2,4 D: 2,4-Dichlorophenoxyacetic acid; AS: Acetoseryngone.

\section{Competing interests}

The authors declare that they have no competing interests.

\section{Author's contribution}

SA and AM performed the experiments, SA wrote the manuscript; SA, AW and BM conceived and designed the experiment and analyzed the data; MEO analyzed the data, BM provides reagents and materails, supervised the study and edits the manuscript.

\section{Acknowledgment}

The authors thank Dr. Ramon Serrano for kindly providing the Agrobacterium tumefaciens strain LBA4404 and the plasmid pJRM17.

\section{Author details \\ ${ }^{1}$ Department of Biochemistry, Quaid-i-Azam University, Islamabad, Pakistan. ²Département de Biologie, Université de Sherbrooke, Québec, Canada. ${ }^{3}$ Horticulture R \& D Centre Agriculture and Agri-Food Canada 430, Boulevard Gouin, St-Jean-sur-Richelieu, Québec, Canada. ${ }^{4}$ Department of Pharmaceutical Sciences, COMSATS Institute of Information Technology, Abbottabad 22060, Pakistan. ${ }^{5}$ Department of Botany, University of Arid Agriculture, Rawalpindi, Pakistan.}

Received: 21 October 2011 Accepted: 1 June 2012 Published: 12 June 2012

\section{References}

1. Jia-Long Y, Jin-Hu W, Gleave AP, Morris BAM: Transformation of citrus embryogenic cells using particle bombardment and production of transgenic embryos. Plant Sci 1996, 113(2):175-183.

2. Fleming $\mathrm{GH}$, Olivares-Fuster O, Del-Bosco S, Grosser JW: An alternative method for the genetic transformation of sweet orange. In Vitro Cell Dev-PI 2000, 36(6):450-455.

3. Nuria Soler, Montserrat Plomer, Carmen Fagoaga, Pedro Moreno, Luis Navarro, Ricardo Flores, Leandro Pena L: Transformation of Mexican lime with an intron-hairpin construct expressing untranslatable versions of the genes coding for the three silencing suppressors of Citrustristeza virus confers complete resistance to the virus. Plant Biotech J 2012, 1-12.

4. de Oliveira M, et al: High-efficiency Agrobacterium-mediated transformation of citrus via sonication and vacuum infiltration. Plant Cell Rep 2009, 28(3):387-395.
5. Yang $L, H u C$, et al: Transformation of sweet orange [Citrus sinensis (L.) Osbeck] with pthA-nls for acquiring resistance to citrus canker disease. Plant Mol Biol 2011, 75(1):11-23.

6. Soler N, Plomer M, et al: Transformation of Mexican lime with an intronhairpin construct expressing untranslatable versions of the genes coding for the three silencing suppressors of Citrus tristeza virus confers complete resistance to the virus. Plant Biotechnol J 2012, 1467-7652.

7. Cervera M, Pina J, Juarez J, Navarro A, Navarro L, Pena L: Agrobacteriummediated transformation of citrange: Factors affecting transformation and regeneration. Plant Cell Rep 1998, 18(3):271-278.

8. Luth D, Moore G: Transgenic grapefruit plants obtained by Agrobacterium tumefaciens-mediated transformation. Plant Cell Tiss Org 1999, 57(3):219-222

9. Peña L, Cervera M, Juarez J, Navarro A, Pina JA, Navarro L: Genetic transformation of lime (Citrus aurantifolia swing.): Factors affecting transformation and regeneration. Plant Cell Rep 1997, 16(11):731-737.

10. Yang ZN, Ingelbrecht IL, Louzada E, Skaria M, Mirkov TE: Agrobacterium-mediated transformation of the commercially important grapefruit cultivar Rio Red (Citrus paradisi Macf.). Plant Cell Rep 2000, 19(12):1203--1211.

11. Bond JE, Roose ML: Agrobacterium-mediated transformation of the commercially important citrus cultivar washington navel orange. Plant Cell Rep 1998, 18(3):229-234.

12. Gutiérrez EMA, Luth D, Moore GA: Factors affecting Agrobacteriummediated transformation in citrus and production of sour orange (Citrus aurantium L.) plants expressing the coat protein gene of citrus tristeza virus. Plant Cell Rep 1997, 16(11):745-753.

13. Peña L, Cervera M, Juarez J, Navarro A, Pina JA, Duran-Vila N, Navarro L: Agrobacterium-mediated transformation of sweet orange and regeneration of transgenic plants. Plant Cell Rep 1995, 14(10):616-619.

14. Hardy S: Growing lemons in Australia- a production manual - Readers' Note in Lemon Growing Manual 2004. www.austcitrus.org.au.

15. Ali S, Mirza B: Micropropagation of rough lemon (Citrus jambhiri lush.): Effect of explants type and hormone concentration. Acta Bot Croat 2006, 65(2):137-146

16. Kaneyoshi J, Kobayashi S, Nakamura Y, Shigemoto N, Doy Y: A simple and efficient gene transfer system of trifoliate orange (Poncirus trifoliata Raf.). Plant Cell Rep 1994, 13(10):541-545.

17. Domínguez A, Guerri J, Cambra M, Navarro L, Moreno P, Pena L: Efficient production of transgenic citrus plants expressing the coat protein gene of citrus tristeza virus. Plant Cell Rep 2000, 19(4):427-433.

18. Mahmoudian M, Yocel M, Oktem HA: Transformation of lentil (Lens culinaris M.) cotyledonary nodes by vacuum infiltration of Agrobacterium tumefaciens. Plant Mol Biol Rep 2002, 20:251-257.

19. Gelvin SB: Agrobacterium-mediated plant transformation: the biology behind the "gene-jockeying" tool. Microbiol Mol Biol Rev 2003, 67:16-37.

20. Sheikholeslam SN, Weeks DP: Acetoseryngone promotes high efficiency transformation of Arabidopsis thaliana explants by Agrobacterium tumefaciens. Plant Mol Biol 1987, 8(4):291-298.

21. James DJ, Uratsu S, Cheng J, Negri P, Viss P, Dandekar AM: Acetoseryngone and osmoprotectants like betaine or proline synergistically enhance Agrobacterium-mediated transformation of apple. Plant Cell Rep 1993, 12 (10):559-563.

22. Janssen B, Gardner R: The use of transient GUS expression to develop an Agrobacterium-mediated gene transfer system for kiwifruit. Plant Cell Rep 1993, 13(1):28-31.

23. Cervera M, Juarez J, Navarro A, Pina J, Duran-Vila N, Navarro L, Pena L. Genetic transformation and regeneration of mature tissues of woody fruit plants bypassing the juvenile stage. Transgenic Res 1998, 7(1):51-57.

24. Ghorbel R, Juarez J, Navarro L, Pena L: Green fluorescent protein as a screenable marker to increase the efficiency of generating transgenic woody fruit plants. Theor App/ Genet 1999, 99(1):350-358.

25. Costa MGC, Otoni WC, Moor GA: An evaluation of factors affecting the efficiency of Agrobacterium-mediated transformation of Citrus paradisi (Macf.) and production of transgenic plants containing carotenoid biosynthetic genes. Plant Cell Rep 2002, 21(4):365-373.

26. Duran-Vila N, Ortega V, Navarro L: Morphogenesis and tissue cultures of three Citrus species. Plant Cell Tiss Org 1989, 16(2):123-133.

27. McGranahan GH, Leslie CA, Uratsu SL, Lori AM, Abhaya MD: Agrobacteriummediated transformation of walnut somatic embryos and regeneration of transgenic plants. Nat Biotechnol 1988, 6(7):800-804 
28. James DJ, Passey AJ, Barbara DJ, Bevan M: Genetic transformation of apple (Malus pumila Mill.) using a disarmed Ti-binary vector. Plant Cell Rep 1989, 7(8):658-661.

29. Mante S, Morgens PH, Scorza R, Cordts JM, Callahan AM: Agrobacteriummediated transformation of plum (Prunus domestica L.) hypocotyl slices and regeneration of transgenic plants. Nat Biotechnol 1991, 9(9):853-857.

30. Tinland B: The integration of T-DNA into plant genomes. Trends Plant Sci 1996, 1:178-184.

31. Bundock P, Hooykaas PJ: Integration of Agrobacterium tumefaciens T-DNA in the Saccharomyces cerevisiae genome by illegitimate recombination. Proc Natl Acad Sci USA 1996, 93:15272-15275.

32. Zhong YH, Wang XL, Wang TH, Jiang Q: Agrobacterium-mediated transformation (AMT) of Trichoderma reesei as an efficient tool for random insertional mutagenesis. Appl Microbiol Biotechnol 2007, 73:1348-1354.

33. Moore GA, Jacono CC, Neidigh JL, Lawrence SD, Cline K: Agrobacteriummediated transformation of citrus stem segments and regeneration of transgenic plants. Plant Cell Rep 1992, 11(5):238-242

34. Murashige T, Skoog F: A revised medium for rapid growth and bioassays with tobacco tissue cultures. Physiol Plantarum 1962, 15:472-493.

35. Hoekema A, Hirsch PR, Hooykaas PJJ, Schilperoort RA: A binary plant vector strategy based on separation of vir- and T-region of the Agrobacterium tumefaciens Ti-plasmid. Nature 1983, 303(5913):179-180.

36. Arrillaga I, Gil-Mascarell R, Gisbert C, Sales E, Montesinos C, Serrano R, Moreno $\checkmark$ : Expression of the yeast HAL2 gene in tomato increases the in vitro salt tolerance of transgenic progenies. Plant Sci 1998, 136(2):219-226.

37. Jefferson RA, Kavanagh TA, Bevan MW: GUS fusion: $\beta$-glucuronidase as a sensitive and versatile gene marker in higher plants. EMBO J 1987, 6:3901-3907.

38. Doyle JJ, Doyle JL: Isolation of plant DNA from fresh tissue. Focus 1990, 12 (1):13-15.

doi:10.1186/1756-0500-5-285

Cite this article as: Ali et al:: Agrobacterium-mediated transformation of rough lemon (Citrus jambhiri Lush) with yeast HAL2 gene. BMC Research Notes 2012 5:285.

\section{Submit your next manuscript to BioMed Central and take full advantage of:}

- Convenient online submission

- Thorough peer review

- No space constraints or color figure charges

- Immediate publication on acceptance

- Inclusion in PubMed, CAS, Scopus and Google Scholar

- Research which is freely available for redistribution 